\title{
The Productivity Effects of Worker Participation: Producer Cooperatives in Western Economies ${ }^{1}$
}

\author{
SAUL ESTRIN \\ Department of Economics, London School of Economics, \\ Houghton Street, London WC2A 2AE, England
}

DEREK C. JONES

Department of Economics, Hamilton College, Clinton, New York 13323

\begin{abstract}
AND
JAN SVEJNAR

Department of Economics, University of Pittsburgh, Pittsburgh, Pennsylvania 15260

Received November 28, 1984; revised June 23, 1986

Estrin, Saul, Jones, Derek C., and Svejnar, Jan-The Productivity Effects of Worker Participation: Producer Cooperatives in Western Economies

The paper presents econometric estimates of productivity effects of various forms of worker participation in Western producer cooperatives. While the effects vary across institutional settings, the overall effect is found to be positive. The positive effects are found most uniformly with respect to profit sharing and, to a slightly lesser extent, individual capital (share) ownership and participation in decision-making by workers. The size of individual worker loans to the coop is unrelated to productivity, while collective capital ownership exhibits an insignificant or a negative productivity effect. (C) 1987 Academic Press, Inc.
\end{abstract}

Journal of Economic Literature Classification Numbers: 226, 514, 825.

\footnotetext{
${ }^{1}$ Data collection was supported largely by a grant from the Leverhulme Trust and NSF Grant SES 8309608. Many individuals cooperated in this process, especially for Italy, Alberto Zevi; for France, Antoine Antoni, Dominic Shafran, and Francois Espagne; and for Britain, Roy Garrett and Lloyd Williamson. The computational assistance of $\mathrm{M}$. Lynch and D. Frecaut is gratefully acknowledged. The paper benefitted from comments by Josef $C$. Brada, two anonymous referees, and seminar participants at the European University Institute in Florence, Italy, the Catholic University of Louvain in Louvain-la-Neuve, France, and the University of Manchester, United Kingdom. It was completed while Jones was a German Marshall Fund Research Fellow and Svejnar a CORE and NSF-NATO Fellow. Estrin and Svejnar also benefitted from a NATO collaborative Research Grant No. RG. 85/0432.
} 


\section{INTRODUCTION}

Since an increasing number of firms around the world are being administered in a participatory manner, interest in policies geared toward these firms is growing. ${ }^{2}$ Although many advocates stress welfare aspects of worker participation in justifying supportive intervention, the question of operational efficiency is clearly a crucial and as yet an unresolved one. At present, there is little published information on the diverse ways that participatory firms are organized, let alone formal modeling or empirical evidence on the relationship between worker participation and enterprise productivity. In consequence, little is known about the effects of increased participation on corporate performance or whether the effects themselves vary according to the type of firm under consideration and the form of participation. In this paper we focus on these issues within the framework of producer cooperatives (PCs) in several Western economies.

In Section 2 we review the economic literature to generate testable hypotheses about the possible productivity effects of worker participation. We note that theorists have been unable to determine unambiguously how worker participation will affect performance, a failure that highlights the need for further theoretical and empirical work. Our aim in Section 3 is to provide comparative institutional material on the diverse ways that PCs, one of the most important types of participatory firms, have been organized in different sectors and countries. The focus is on the scope and nature of PCs in the two largest and most dynamic cooperative sectors in the world, those in France and Italy, as well as one of those in least good health, the long-established British PC sector. We proceed by modifying the theoretical framework to take account of institutional differences and then examining the statistical relationship between worker participation and enterprise performance. Since the same measures of participation are used for different groups of PCs, we are able to report comparable estimates for different countries and institutions. The study is based on evidence from large enterprise-level data sets, some 500 firms over 2 years in France, 140 firms over 5 years in Italy, and 24 firms over 20 years in Britain. Finally the policy implications of our findings are briefly considered.

At first sight, one might be suspicious of conclusions about the effects of participation deduced from a data set containing only producer cooperatives. For example, the implicit self-selection of workers and managers might lead to problems in generalizing the results to capitalist firms. This is clearly a problem but in our sample it is not as serious as it may seem. The reason is that legally many types of firms are cooperatives, including enterprises in

\footnotetext{
${ }^{2}$ For example, the European Parliament recently published a report from the Mihr Committee supporting the notion of cooperation; several European countries have introduced laws requiring worker-directors and a Cooperative Bank was established in the United States in 1980.
} 
which all workers are participants and companies founded many years ago as coops but now owned by nonworkers and run as private companies. This diversity allows us to analyze within our data set the effects of varying degrees and forms of participation in different sectors and countries and to draw conclusions that have some validity beyond the cooperative sector per se. ${ }^{3}$

As our research has proceeded, the evidence has also begun to convince us that the European cooperative sector is an interesting topic of study in its own right. The traditional picture of the coop sector is one of small inefficient firms unable to survive long in the competitive capitalist environment because of managerial and financing problems. In fact, in Italy and France there are very large, long-established, and successful cooperative sectors employing more people and playing a greater role in the economy than the better known but also highly successful Mondragon group in the Basque region of Spain. Moreover, the cooperative sector in all Western European countries has grown significantly in recent years, for example, from about a dozen firms in the United Kingdom in 1970 to about 900 in 1984 and from 300 to 1400 firms in France over the same period (see Estrin, 1986). This can in large part be attributed to government policy and in particular to the creation of diverse supporting organizations. It is hoped that our findings will contribute to the formulation of further policy guidelines, particularly with respect to the internal organization of the PC.

\section{PREDICTIONS FROM ECONOMIC THEORY}

There has been relatively little formal modeling of the relationship between enterprise productivity and worker participation in decision-making, profit, and ownership of assets. The existing work is not based on rigorous theory and we therefore restrict ourselves to surveying the general themes to clarify the issues at stake.

Participation in decision-making, profit, and ownership is hypothesized to affect company productivity via the productive skills of the labor force, workers' effort or intensity of work, and the firm's organizational efficiency. Researchers in the area can be divided into those who think that the effects will be positive and those who argue that they will be negative. Each prediction is typically made without reference to the nature of the organization or the type of participation. On the positive side it is argued that the workers' propensity to stay with the firm and therefore augment their firm-specific human capital and productivity is an increasing function of the degree of participation. Participation can also be expected to improve the functioning of work groups within the firm and to reduce the difficulty of obtaining an optimal labor mix,

\footnotetext{
${ }^{3}$ Note also that our sample does not correspond to the traditional image of coops as small and often undercapitalized firms. As we observe later, many of the PCs are equivalents of Fortune 500 companies in the U.S.
} 
thereby raising company productivity. Furthermore, a more participatory firm might be expected to have superior conflict resolution and therefore fewer strikes or work stoppages. In such companies the average labor tenure would be longer, and this would generate better incentives for individuals to acquire human capital and for firms to train their labor forces. Participation might also be expected to internalize some of the material and nonmaterial externalities associated with the production process.

Turning to the relationship between participation and effort, there are numerous reasons why employees in participatory firms might be expected to work harder. Participation in decision-making, profits, and ownership is likely to generate superior labor morale and therefore work quality via both team spirit and sharper material incentives for effort. The morale effect may also create peer group pressures for lower absenteeism, better workmanship, and superior monitoring of effort and quality. Finally, participation may improve firms' overall organizational efficiency, flexibility, and willingness to innovate, particularly with respect to production processes. Specifically, one might expect the better communication implicit in such organizations to facilitate the free flow and use of information about ways to improve productivity rising from the shop floor, and to reduce workers' suspicions of new work methods and practices. ${ }^{4}$

On the negative side, the strongest case is made by Jensen and Meckling (1979), who see participation as always having deleterious effects on productivity. Firms providing opportunities for participation in decision-making, profits, and ownership are therefore always expected to do worse than other enterprises. The pessimists focus on information sharing and joint decisionmaking, but they suggest that these features will lead to poor choices if the workers do not have the appropriate expertise, particularly in finance and marketing. Inefficiencies may also result from participation in decision-making because of problems in group preference formation when workers' tastes differ. Even if this social choice problem can be overcome, it is suggested that participative decision-making will be slow and cumbersome. Moreover, if the participating workers have inappropriate attitudes to risk, either because participation involves them in holding an inefficient asset portfolio or by temperament, they will invest less than their capitalist counterparts.

A second strand of the argument stresses the role of management. If workers' participation entails less power and authority for managers, and if managerial input is crucial for corporate performance, then participation will be inversely associated with efficiency because of managerial shirking. ${ }^{5}$ The monitoring

\footnotetext{
${ }^{4}$ For a more complete discussion of these arguments, see Jones and Svejnar (1985).

${ }^{5}$ Earlier the Webbs (1920) claimed that worker control would cause serious inefficiencies because of the alleged inability of a manager to effectively oversee his subordinates who had the power to discharge him.
} 
argument is also used to support the claim that participation in profits by workers will produce inefficiencies (Alchian and Demsetz, 1972). It is argued that as the labor force grows, each individual will have a stronger incentive to shirk, and so shirking will become more difficult and expensive to detect. Worker participation is expected to be particularly dysfunctional in large firms.

Some authors on the optimistic side have tried to derive specific predictions from this general analysis. Vanek $(1970,1975)$ and Horvat (1982) argue that PCs have to be structured in particular ways for the full productivity effects to be realized. It is organizations that come closest to their highly democratic and egalitarian structure that will be expected to perform best. Vanek believes that the productivity gains come primarily through workers' involvement in decision-making and sees material incentives, the most important of which is profit-sharing, as subordinate. Horvat also stresses genuine worker power, though for him participation in ownership, which is discouraged by Vanek, may be a practical necessity. Cable and Fitzroy's (1980a,b) conceptual framework stresses both material and nonmaterial causes and argues that there are powerful interactions among the various channels, notably between surplus sharing and participation in decision-making. But for Oakeshott (1978; see also Clayre, 1980), it is material incentives that matter most; a large individually owned capital stake is viewed as essential for producing high productivity. The propositions on the pessimistic side tend to be more all-encompassing, though managerialists would tend to be particularly suspicious of participation in decision-making while property rights analysts would tend to stress the negative role of worker capital stakes and of profit sharing.

The general theoretical literature therefore offers competing hypotheses on the direction and scale of the participatory effect, with the further suggestion that results may hinge on the organizational structure of the firm. The dominant test in the literature (for a survey see Jones and Backus, 1977; Cable and Fitzroy, 1980a,b; Jones and Svejnar, 1982) focuses on general predictions. It involves including a participatory variable in a production function, normally assumed to be of Cobb-Douglas form, and testing hypotheses about the sign and significance of the included variable. This fails to take account of the marked variation in market circumstances, internal organization, and mode and degree of participation in different enterprises discussed in the following section. In our empirical work, we control for differences in market structure and internal organization and allow for differences in production technology by testing for the functional form best supported by the data. Moreover, we distinguish among three possible channels of participation: in profits, in ownership, and in decision-making.

We therefore examine how differences in the organization of coops across countries and sectors affect the direction and scale of the participatory effects. Light is cast on the general hypothesis from theory by isolating whether there are any common patterns in the direction of particular effects across countries, 
sectors, industries, and years. We also investigate whether, as more careful theorists have suggested, the direction of the participatory effect is sensitive to organizational form and to the particular channel and degree of participation. The approach is in the spirit of Nelson (1981), who suggests that, because most empirical work by economists omits important variables such as job satisfaction, one might expect participatory effects to differ by firm, sector, year, and type of firm.

\section{THE DIVERSITY OF WESTERN EUROPEAN COOPERATIVES}

Since our econometric work hinges on the way that cooperative structures and choices differ by sector and country, it is important to provide information on the varying institutional arrangements as well as stylized facts on the issues under consideration. We start by pointing out the substantial differences that exist between PCs and their capitalist or state-owned counterparts. A PC is an enterprise in which

(a) many workers are "members" of the firm, where membership is normally via individual ownership of stock;

(b) worker-members participate in control and management of the firm;

(c) control is usually on the basis of one member-one vote. Where voting rights vary directly with stock ownership, there is an absence of concentrated stock ownership;

(d) worker-members share in profits.

Numerous firms with these characteristics have existed in industrialized Western economies, but our attention is concentrated on those PCs which are the subject of our statistical analysis. ${ }^{6}$ The discussion is organized around Table 1 which summarizes the comparative statistical information for these PCs, and also includes comparative information for Mondragon (Spain) PCs and U.S. plywood coops, cases that have received much attention in the literature.

\section{Scope and History}

In Italy, the postwar period saw a phenomenal growth of PCs in two phases, between 1945 and 1947 and from 1970 to the present (Jones and Zevi, 1983), so that by 1981 there were almost 20,000 registered PCs. This makes the Italian grouping by far the largest in Western industrialized countries, employing around 200,000 people. The number of PCs in France grew gradually

\footnotetext{
${ }^{6}$ For general discussions which provide more detail on other dimensions of PCs-empirical, historical, and sociological-see Oakeshott (1978), Jones (1980), and Thornley (1981). For greater detail on specific PCs, see Thomas and Logan (1982) on Mondragon; Gunn (1984) Jones (1979, 1984) on U.S. PCs; Jones and Zevi (1983) on Italian PCs; Jones (1982) on British PCs; and Batstone (1982) on French PCs.
} 
since 1945, reaching around 500 in the 1970s (Estrin and Jones, 1983). There was a rapid upsurge, however, after 1977, with the population reaching almost 700 in 1979 and 1000 in the early 1980 s. In providing jobs for about 40,000 workers, the French PC sector is the second largest in the West. The oldest surviving PCs in Britain have been in existence for more than 100 years, but no firms in this traditional group have been formed since 1950 . Total employment in long-established British PCs was about 3400 in 1968 but this had been halved by $1980 .^{7}$ Today the British PC sector is the smallest of the five under examination in this paper. ${ }^{8}$

While Italian PCs have recently increased their influence in the service sector, they are active mainly in construction and manufacturing. They are estimated to account for about $8 \%$ of the sales in building and construction, and their market share is reported to be about $10 \%$ in the manufacture of pottery, woodwork finishings, glass making, and certain mechanical engineering activities. French PCs have traditionally been concentrated in construction, printing, and electrical engineering. These areas were still important in the late 1970s, accounting for about 50,12 , and $10 \%$ of our sample, respectively, but their relative significance has been diminished by the emergence of three new groupings. In one, people with relatively high qualifications have begun to provide diverse professional and cultural services. This consultancy grouping is already the second most numerous, accounting for about $15 \%$ of the sample. The other new groups provide more general services and produce mechanical goods, each comprising some $8 \%$ of the sample. Traditional British PCs have been concentrated in clothing, footwear, and printing.

${ }^{7}$ In this paper we confine our attention to the less vibrant example of contemporary British PCs. Other British PCs exist. Many have adopted the industrial common ownership movement (ICOM) bylaws and resemble the famous Scott Bader Co. Data for these newer PCs, however, are fragmentary and have not yet been examined in any rigorous way.

${ }^{8}$ By comparison, the first U.S. PCs were established in the late 18 th century and about 800 are known to have been formed up to the early 1970s (see Jones, 1979). The number in the best known group, the plywood PCs, has recently fallen, but the 1970s witnessed the growth of many new PCs, notably in reforestation. The Mondragon (Basque) group of PCs differs markedly from other cooperatives. Starting from nothing in the mid-1950s, an integrated organization of about 19,000 workers has been created covering diversified economic activities including agriculture, retailing, educational institutions, and a bank (see Johnson and Whyte, 1977; Thomas and Logan, 1982). Already this is the third largest PC sector in the West, providing about 16,000 jobs in industrial cooperatives alone.

${ }^{9}$ Most American PCs have been grouped into distinct clusters (Jones, 1977), currently including the well-known plywood coops, reforestation PCs, and taxi driver cooperatives. Recently there has been significant retrenchment in plywood PCs, but the reforestation PCs which first appeared in the 1970s have flourished. In Mondragon, almost one-third of the worker-members work in PCs that produce consumer durables, about one-third in intermediate goods and components, and one-fifth in the production of capital goods. The other main sectors in which Mondragon workers find employment are foundries, forges, and building materials. New British PCs span a wide range of activities, mostly in retail distribution, food processing, printing, and publishing. 


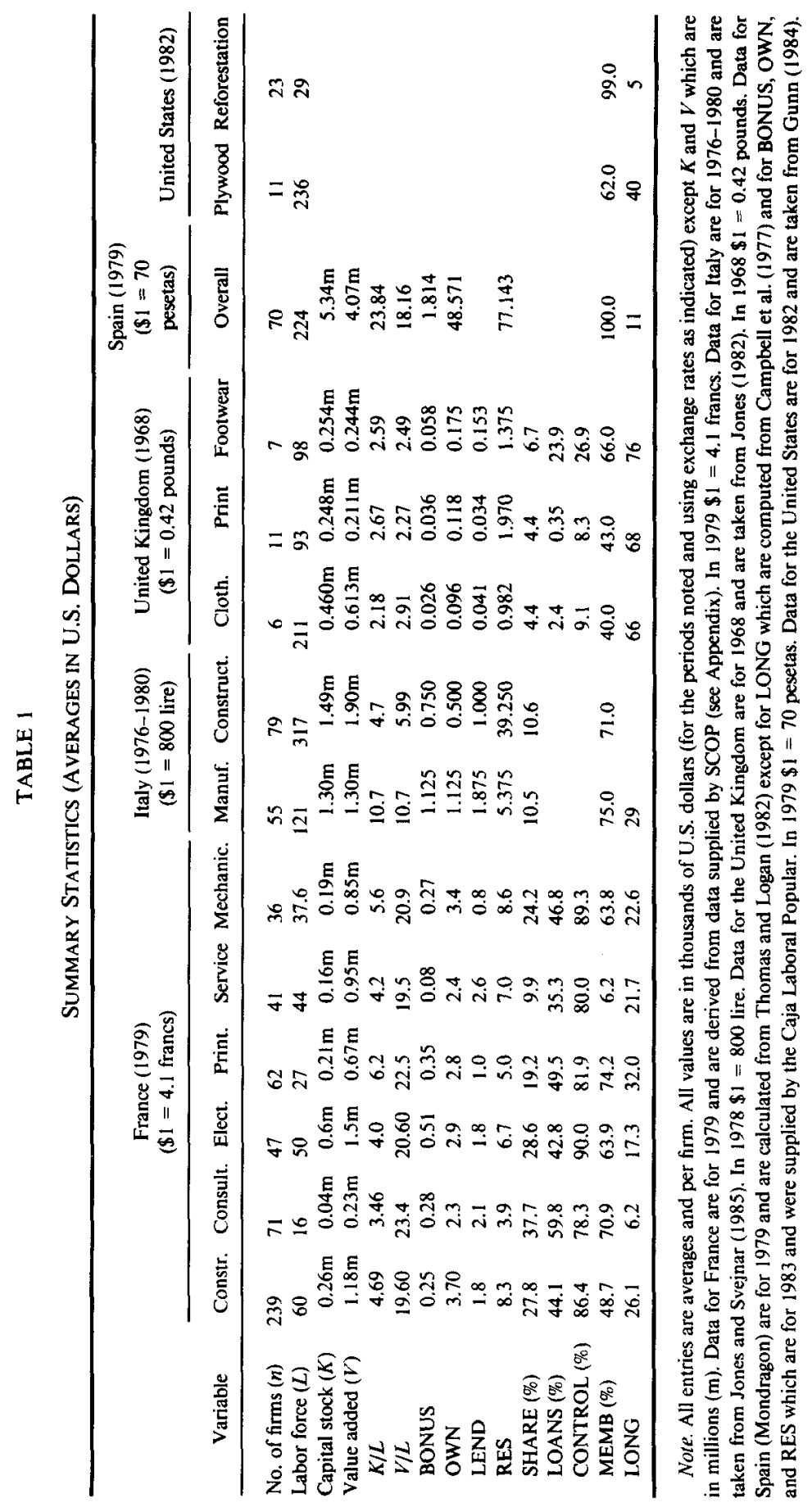


The average Italian PC is small, employing fewer than 20 workers. However, as the sample data described in Table 1 show, there are also many of considerable size. For example, during 1975-1978 the 79 PCs in our sample employed 317 workers on average and generated annual value added of about $\$ 1.9$ million. The existence of many large PCs distinguishes the Italian sector from others in the West. French PCs are on average small, each providing employment for around 50 workers though there is considerable variation from branch to branch, ranging on average from only 16 workers in consultancy to about 60 in construction. Data for 1968 show that on average the largest traditional British PCs are in clothing, with footwear PCs being marginally bigger than those in printing with respect to labor force, value added, and capital stock. But these averages mask considerable variation in the size distribution. ${ }^{10}$

\section{Internal Structure}

Cooperative bylaws normally stipulate that a certain percentage of enterprise surplus must be distributed to workers as a bonus, for example, at least $25 \%$ in French PCs. Non-worker-members usually share in this allocation. The average amount of enterprise surplus allocated to each worker is denoted BONUS in Table 1. In 1979 BONUS amounted to $\$ 80-\$ 510$ in French PCs. These amounts are considerably higher than those in long-established British $P C s$, ranging from $\$ 26$ to $\$ 58$, but below the Italian averages of $\$ 750$ to $\$ 1125$ and the Mondragon figure of more than $\$ 1800$.

Only in the U.S. PCs is there an attempt to provide for equality of incomes of worker-members, although in Mondragon and Italian PCs there are strict limitations on the permissible income differences that may emerge within a firm. No such constraints appear to exist in French and British PCs.

In almost all Western cooperatives, membership is based on capital ownership. In France, the law requires members to own only one share in the firm, but the PCs' own articles of association typically require an additional capital stake. We see in Table 1 that the average worker's capital stake, designated OWN, is higher in the older industries such as construction, electricals, mechanicals, and printing (\$2800-\$3700) and lower in newer ones such as services and consulting (\$2300-\$2400). In Italian PCs, workers cannot hold a share greater than $\$ 5000$, equal to roughly one-half of a worker's average annual income. In practice, actual holdings fall below these maxima, even in

${ }^{10}$ In U.S. plywood PCs, employment averaged 236 in 1982 and their size ranged from 60 to $\mathbf{5 0 0}$ workers. Reforestation PCs are smaller, with the average PC providing jobs for 39 . In the main, U.S. PCs have emerged in trades characterized by a high skill content. Newly established British coops tend to be tiny, employing fewer than 10 workers on average (Cornforth, 1983). Mondragon PCs tend to use more sophisticated technology than elsewhere. As is clear from Table 1, Mondragon PCs are by far the most capital-intensive group of PCs. 
larger PCs. As Table 1 shows, the value of OWN was about $\$ 1125$ in manufacturing PCs and about $\$ 500$ in construction PCs, but these are well above sums held in long-established British PCs, which are between $\$ 100$ and $\$ 200 .{ }^{11}$

Worker ownership can also be proxied by the proportion of the individually owned member capital in the hands of worker-members, denoted CONTROL in Table 1. For French PCs this fraction never falls below the 78\% observed in consultancy firms and it never rises above the $90 \%$ observed in the electricals sector. For both French and British PCs, the measure tells a story about the intersectoral pattern of effective participation similar to that of the previous variable. Data limitations preclude the calculation of CONTROL for the other countries. In Table 1 we also examine the importance of individual worker ownership with the variable SHARE which shows the proportion of the firm's assets owned by worker-members. By this measure, worker members in the older French PCs have less control than workers in the newer sectors, though far more control than workers in the long-established British PCs. Workers in Italian PCs also have less influence than the French on this measure.

Individually owned member shares are paid a limited return in French, Italian, and British PCs. ${ }^{12}$ Shares are repaid at par when members leave and if the coop is dissolved then all net assets devolve to a cooperative fund except in the United Kingdom, where industrial members share the new assets of a dissolved company. ${ }^{13}$ The bulk of finance is therefore provided by collectively owned reserves built up by allocations from the surplus. Sometimes this is mandatory, as in France, where a minimum of $15 \%$ must be reinvested. The differing importance of reserves is indicated by collective reserves per workermember, denoted RES in Table 1. The undercapitalization of British PCs is manifest. Most importantly, Table 1 illustrates the striking dependence on collective as compared with individual ownership in all PCs except the French consultancy and service sectors. For example, in British printing PCs reserves per worker are 16 times as great as individual ownership $(\mathrm{RES} / \mathrm{OWN}=16)$. By contrast, the ratio in Mondragon is about 1.5 .

PCs rarely borrow on the open market, though they do take loans from

"However, these values are markedly below ownership stakes held by Mondragon members, estimated by Thomas and Logan to be as high as $\$ 48,000$ for senior workers. For U.S. plywood firms, since there is neither an active market in plywood shares nor an accounting system corresponding to the sophisticated internal capital accounts method used in Mondragon, it is difficult to establish the average value of worker-members' capital. Gunn (1984) reports shares in the more successful PCs having sold in excess of $\$ 100,000$.

${ }^{12}$ In U.S. PCs, dividends are seldom paid on member capital.

${ }^{13}$ In Mondragon and U.S. plywood PCs the value of an individual member's stake varies, depending on the fortunes of the firm. However, an individual worker in Mondragon can usually liquidate his capital account without penalty only upon retirement. And in U.S. plywood PCs, an individual worker-member who wishes to realize his equity in the coop must, upon leaving, find another worker satisfactory to the remaining workers and with sufficient funds to buy him out. 
specialized financial institutions and, in addition, members often make substantial personal loans to their cooperatives. This may represent a further measure of workers' identification with the enterprise and is denoted LEND in Table 1. In large Italian PCs the individual worker, attracted in part by tax incentives (Jones and Zevi, 1983), loans his firm from $\$ 1000$ in construction to $\$ 1875$ in manufacturing on average, far more than in British PCs $\mathbf{\$ 3 4}$ $\$ 153$ ), U.S. plywood PCs, and Mondragon PCs, though somewhat less than in French PCs, particularly the newer ones. For some countries we can control for the total amount of debt. In France the proportion of loan capital lent by members, denoted LOANS in Table 1, ranges from around 35\% of loan capital on average in service PCs to almost $60 \%$ in the consultancy sector. In the United Kingdom, members' loans are typically a small proportion of debt, except for in the footwear sector.

Though the minimum capital requirements are generally small, not all workers choose to become cooperative members and to thereby gain the right to participate in corporate decision-making. ${ }^{14}$ MEMB in Table 1 represents the proportion of the labor force that chooses to become members and it varies considerably from firm to firm. On average in $1968,66 \%$ of the workers were members in British footwear PCs, although the proportion was only about $40 \%$ in clothing and printing. In French PCs, in only two sectors do more than $70 \%$ of workers become members, which is slightly below the average figure in large Italian PCs. Mondragon membership is required of all permanent workers. ${ }^{15}$

\footnotetext{
${ }^{14}$ Legislation governing PCs exists in most European countries and conforms with the principles of cooperation laid down by the International Cooperative Alliance: one member, one vote; free and voluntary membership; and limited remuneration of the underwritten capital. There is no state or federal legislation that governs the U.S. cooperatives. Sometimes the rules also set limits on the membership size. For example, in Italy, while there is no upper limit on the number of members, there must be no fewer than 9 and, for PCs that participate in public contracts, 25 members are needed. Generally, in France, Italy, and Mondragon only workers can be members of the primary cooperatives. In traditional British PCs typically there are three classes of members: workers, other individuals (particularly former workers), and other societies (particularly retail cooperatives, other PCs, and trade unions).

${ }^{15}$ For each PC movement, important differences also exist with respect to the relationship between PCs and other parts of the labor movement. The best known and most developed structures designed to support primary coops exist in Mondragon (Thomas and Logan, 1982). Of special importance is a cooperative bank that exists to serve all PCs in Mondragon. No such institution exists to serve another group of PCs and usually there are legal restrictions inhibiting a PC's ability to raise outside financing. For example, in Britain preference shares cannot be issued. In France PCs are served by a national federation and several regional federations and specialist associations for building and printing. Cooperation in France is also traditionally well represented in both retail trade and agriculture, but there is little effective collaboration between these cooperatives and PCs or with other segments of the labor movement (Antoni, 1957). By contrast. a major characteristic of the Italian movement is the promotion of close ties; PCs exist as part of an integrated cooperative movement. Strong national organizations of cooperatives and consortia exist to serve PCs (Jones and Zevi, 1983). By comparison, with experiences elsewhere, the second-
} 


\section{ESTIMATING FRAMEWORK}

Our empirical work follows the literature in employing an augmented production function framework. Specifically, we estimate equations of the general form

$$
V=V(K, L, X, Z)
$$

where $V$ denotes value added, $K$ and $L$ represent the capital and labor inputs, respectively, $X$ is a vector of industry- and enterprise-specific variables, and $Z$ is a vector of participatory variables. To see how the participatory variables enter Eq. (1), consider the Cobb-Douglas case when the effects of participation are disembodied. The production function is then

$$
V=A K^{\alpha_{1}} L^{\alpha_{2}} e^{(\gamma Z+\delta X)}
$$

which in a logarithm form becomes ${ }^{16}$

$$
\ln V=\ln A+\alpha_{1} \ln K+\alpha_{2} \ln L+\gamma Z+\delta X .
$$

The $Z$ vector comprises proxies for the three categories of worker participation: surplus sharing, financial commitment to the firm, and decision-making. For France the equations are estimated separately for each sector and the $X$ vector contains dummies for the year and for subsectors of construction. In addition, to test life-cycle theories, variables for the age of the enterprise are included where possible. For Italy and Britain, where our data are in the form of panels, we allow for firm-specific fixed effects and estimate models which do and do not contain firm-specific intercepts.

An important aim of our analysis is to identify the most appropriate form of the production function, in case the effects attributed to the participation variables, when a single functional form is imposed, are in fact due to misspecification of technology. We therefore employ three forms of production technology: the generalized Cobb-Douglas (CD) function, Kmenta's (1967) approximation to the constant elasticity of substitution (CES), and the transcendental logarithmic (translog) function. In each case we select the production function best supported by the data. In particular, denoting firms by $i$, the time period in years by $t(t=1,2, \ldots$, , and the residual by $\mu$, we estimate

$$
\begin{aligned}
& \ln V_{i t}=\alpha_{0}+\alpha_{1} \ln K_{i t}+\alpha_{2} \ln L_{i t}+\alpha_{3} Z_{i t}+\alpha_{4} X_{i t}+\mu_{i t} \\
& \ln V_{i t}=\beta_{0}+\beta_{1} \ln K_{i t}+\beta_{2} \ln L_{i t}+\beta_{3} Z_{i t}+\beta_{4} X_{i t}+\beta_{5}\left[\ln \left(K_{i t} / L_{i t}\right)\right]^{2}+\mu_{i t}
\end{aligned}
$$

/third-degree structures that exist to serve either U.S. or British primary PCs are primitive. While U.S. plywood and reforestation PCs, for example, do belong to federations, the nature and scope of these structures and the range of services that they provide are very limited.

${ }^{16}$ For a fuller exposition of this estimating framework, see Jones and Svejnar (1985). 


$$
\begin{aligned}
\ln V_{i t}=\gamma_{0}+\gamma_{1} \ln K_{i t}+\gamma_{2} \ln & L_{i t}+\gamma_{3} Z_{i t}+\gamma_{4} X_{i t} \\
& +\gamma_{5}\left[\ln L_{i t}\right]^{2}+\gamma_{6}\left[\ln K_{i t}\right]^{2}+\gamma_{7} \ln K_{i l} \ln L_{i t}+\mu_{i t}
\end{aligned}
$$

and we use $F$ tests as well as Davidson and MacKinnon's (1981) $J$ test to select the most appropriate functional form.

In the following section we report the results from regressions based on common sets of functional forms, specifications, and sets of participatory and control variables for the United Kingdom, France, and Italy. The aim is to search for common patterns and highlight intercountry differences which could be associated with national characteristics such as the existence or absence of supporting organizations. We have reported elsewhere on intercountry studies in which we relax the constraints imposed by the need for intercountry comparability, for example, by using CONTROL as a participatory variable for French PCs (see Estrin and Jones, 1983; Jones and Svejnar, 1985).

In view of the superior robustness of ordinary least-squares (OLS) estimates against specification errors relative to simultaneous equations methods, we first report OLS results. However, since endogeneity of regressors may be a problem in our functional specification, especially with respect to $Z$, we also report the main estimates from specifications based on instrumental variables (IVs).

\section{EMPIRICAL RESULTS}

Our econometric work is based on the three enterprise-level data sets described in Table 1, covering around 500 French PCs in 1978 and 1979, 150 Italian PCs for 1976 to 1980, and some 50 long-established British PCs for 5 -year intervals between 1948 and 1968 . The main OLS results are reported in Table 2 and variable definitions are contained in the Appendix.

The OLS estimates point to differences in the preferred functional form. In the United Kingdom, the estimated Cobb-Douglas and disembodied translog production functions overwhelmingly reject the firm-specific fixedeffects specification in favor of the one with a single intercept. In the latter specification the disembodied Cohb-Douglas form dominates CES and translog. For Italian PCs, however, fixed-effect models are superior and in manufacturing translog dominates Cobb-Douglas and CES. Finally, in France, while we are unable to test for the fixed-effects specification, we find that the translog form dominates Cobb-Douglas and CES in all sectors except construction and electricity.

To test whether the existing participatory schemes have any effect on performance we use an $F$ test on the joint exclusion of the five participatory variables from the augmented production function. In all 10 cases across the three countries this leads us to reject the hypothesis that the various forms of participation, taken together, do not affect productivity. Moreover, in the case of the French PCs, where the coefficient signs on all the participatory variables 


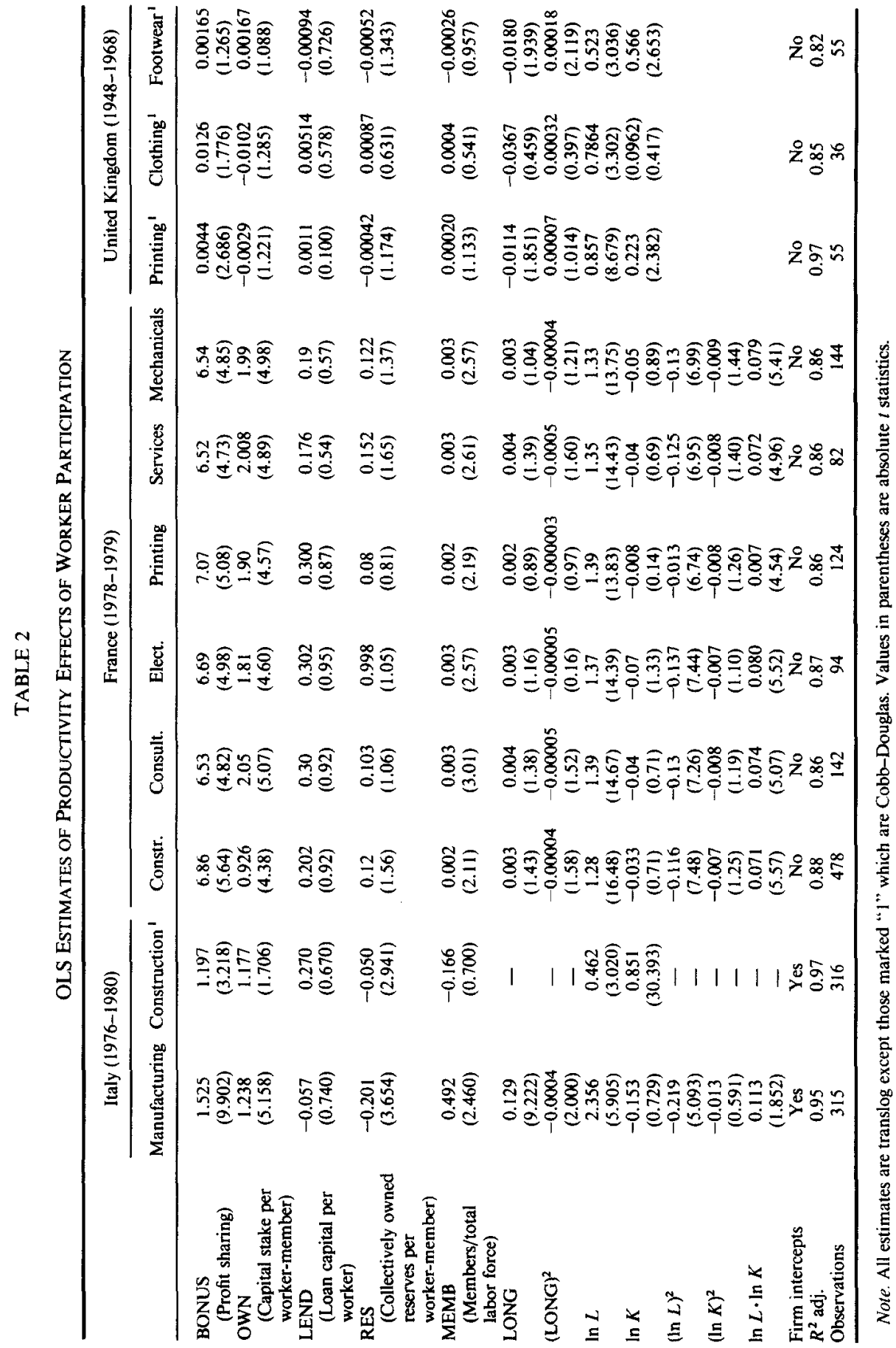


are positive, the results strongly support the hypothesis that participation increases enterprise output. However, in the case of all three countries one finds some coefficients to be statistically insignificant and in the two Italian sectors the significant coefficients on the participatory variables display both positive and negative signs. The results hence point to the significance of the productivity effects of participation, but they also indicate that the effects are sensitive to the form of participation. In terms of the ongoing debate, our findings definitely contradict the entirely pessimistic propositions of, for example, Jensen and Meckling (1979), and suggest that some forms of worker participation tend to improve productive performance.

When one examines the productivity effects of the individual participatory schemes, several interesting patterns emerge. The most striking result concerns the profit-sharing variable, BONUS, whose estimated coefficient is positive and statistically significant in all 11 cases, a remarkable degree of consistency across sectors and countries.

Turning to the three proxies for workers' financial commitment, OWN, LEND, and RES, we find that OWN (individual capital ownership per worker) has a positive and significant effect in all six French sectors as well as in Italian manufacturing. Moreover, in Italian construction the estimated coefficient is positive and close to being significant at conventional statistical significance test levels. However, in the United Kingdom, where individual ownership stakes are typically very low, the coefficient on OWN is found to be statistically insignificant.

It is remembered from Table 1 that, in general, workers' stakes in the firm via short-term loans are greater than those via individual ownership. However, the coefficient on the LEND variable is insignificant in all the regressions. The average size of individual member loans to the PC hence appears to be completely unrelated to the firm's productive efficiency.

The effect of average collective ownership of the firm's assets by worker members, RES, varies across countries. It is significantly negative in the two Italian sectors and not significantly different from zero in France and in the United Kingdom.

The remaining element of the $Z$ vector is worker participation in decisionmaking, measured by MEMB. This is found to enhance corporate productivity significantly in Italian manufacturing and in all the French sectors, but the coefficient is insignificant in Italian construction and in the three British industries. The insignificance of the MEMB coefficient in the Italian construction sector may be caused by data limitations. In contrast to manufacturing, where data on current (active) members could be used to construct MEMB, the MEMB variable in construction includes both the current and the retired worker-members. The British results clearly stand out and once again raise the question of why one finds so many insignificant effects in this system of PCs. However, it should be noted that the British results are sensitive to the 
choice of the relevant proxy variable. When the proportion of the board of directors that is worker-members is used as an alternative measure of worker participation in the British PCs, the variable enters the Cobb-Douglas production function with a positive and significant coefficient.

If we briefly consider the OLS results by country, we find participatory effects to be the strongest and most common in Italy and France, countries with relatively high average degrees of participation, strong cooperative traditions, and well-organized supporting institutions. In the United Kingdom, where the average levels of participation are much lower, worker cooperative traditions are less generally established, and the supporting organizations are much weaker, the effects of participation on performance, though positive when significant, are few and far between.

The data sets provide only limited support for the life-cycle hypothesis about productive performance. The longevity of the firm (LONG) could be measured in all the French sectors, in Italian manufacturing, and in the British printing, clothing, and footwear samples. Entering this variable quadratically produces the expected concave and initially increasing productivity profile in the Italian and French PCs but the relationship is statistically significant in only the former case. In the British PCs the estimated life-cycle profile is flat in clothing and is downward sloping, although convex, in printing and footwear. Moreover, even the Italian finding is not overwhelmingly supportive of the hypothesis since the estimated productivity decline sets in only at the age of 161 years.

The usefulness of the IV estimates that we have produced to overcome the potential endogeneity of regressors depends critically on the availability of suitable instruments. This turned out to be no problem in the case of the Italian and British data sets where a sufficiently long panel exists for each firm. The correlation between the original regressors and the exogenous instruments is high and the estimated IV coefficients are very similar to the OLS ones in these two countries. ${ }^{17}$

The French PCs data cover only 2 years and the predictive power of the available instrumental variables is rather limited. The resulting IV estimates differ in several respects from their OLS counterparts and are therefore presented in detail in Table 3. The most striking finding is that the coefficient on BONUS changes from being highly significant in Table 2 to being insig-

\footnotetext{
${ }^{17}$ For instance, the IV estimates (absolute $t$ statistics) based on a disembodied Cobb-Douglas specification are as follows. Italian manufacturing: BONUS 1.632 (7.19), OWN 1.584 (3.90), LEND 0.065 (0.34), RES - 0.312 (3.06), and MEMB 0.529 (1.82); Italian construction: BONUS 6.475 (6.41), OWN 9.265 (6.01), LEND 5.827 (6.68), RES -0.250 (5.43), and MEMB -0.798 (1.35); British printing: BONUS 0.0048 (2.576), OWN -0.0040 (1.342), LEND $0.0021(0.220)$, RES -0.0003 (1.385), and MEMB 0.0001 (1.341). These estimates are based on instrumental variable equations with indexes of product prices, capital goods prices, material prices, and firmspecific dummy variables interacted with time serving as instruments.
} 
nificant in all but one case, printing, in Table 3. The MEMB variable displays positive coefficients throughout and in three of the six cases they are statistically significant at the 5\% level. OWN registers two positive and statistically sig-

TABLE 3

IV Estimates of Productivity Effects of Worker Participation in French PCs

\begin{tabular}{|c|c|c|c|c|c|c|}
\hline & Construction & Printing & Services & Consultancy & Mechanicals & Electricals \\
\hline BONUS & $\begin{array}{c}-4.81 \\
(0.96)\end{array}$ & $\begin{array}{l}27.55 \\
(2.31)\end{array}$ & $\begin{array}{l}48.21 \\
(0.95)\end{array}$ & $\begin{array}{l}10.87 \\
(1.36)\end{array}$ & $\begin{array}{l}12.01 \\
(0.49)\end{array}$ & $\begin{array}{l}14.52 \\
(1.42)\end{array}$ \\
\hline MEMB & $\begin{array}{c}0.01 \\
(5.13)\end{array}$ & $\begin{array}{c}0.003 \\
(1.09)\end{array}$ & $\begin{array}{c}0.004 \\
(1.05)\end{array}$ & $\begin{array}{r}0.001 \\
(0.23)\end{array}$ & $\begin{array}{c}0.01 \\
(3.89)\end{array}$ & $\begin{array}{c}0.01 \\
(2.42)\end{array}$ \\
\hline OWN & $\begin{array}{c}0.85 \\
(1.24)\end{array}$ & $\begin{array}{c}4.48 \\
(1.96)\end{array}$ & $\begin{array}{c}2.80 \\
(1.00)\end{array}$ & $\begin{array}{c}-1.98 \\
(0.62)\end{array}$ & $\begin{array}{c}5.72 \\
(2.20)\end{array}$ & $\begin{array}{c}-3.82 \\
(1.30)\end{array}$ \\
\hline LEND & $\begin{array}{c}2.00 \\
(2.21)\end{array}$ & $\begin{array}{c}-8.64 \\
(2.03)\end{array}$ & $\begin{array}{c}-0.25 \\
(0.15)\end{array}$ & $\begin{array}{c}1.44 \\
(0.57)\end{array}$ & $\begin{array}{c}-3.71 \\
(1.54)\end{array}$ & $\begin{array}{c}1.83 \\
(0.97)\end{array}$ \\
\hline RES & $\begin{array}{c}1.10 \\
(3.98)\end{array}$ & $\begin{array}{c}-0.94 \\
(0.90)\end{array}$ & $\begin{array}{c}0.23 \\
(0.44)\end{array}$ & $\begin{array}{c}-2.93 \\
(2.92)\end{array}$ & $\begin{array}{c}0.22 \\
(0.43)\end{array}$ & $\begin{array}{c}-0.04 \\
(0.05)\end{array}$ \\
\hline Long & $\begin{array}{c}-0.004 \\
(0.97)\end{array}$ & $\begin{array}{c}0.002 \\
(0.41)\end{array}$ & $\begin{array}{c}0.40 \\
(2.66)\end{array}$ & $\begin{array}{c}0.30 \\
(0.98)\end{array}$ & $\begin{array}{c}0.02 \\
(1.31)\end{array}$ & $\begin{array}{l}0.0028 \\
(0.16)\end{array}$ \\
\hline Long $^{2}$ & $\begin{array}{l}0.000001 \\
(0.03)\end{array}$ & $\begin{array}{c}-0.00004 \\
(0.58)\end{array}$ & $\begin{array}{c}-0.0006 \\
(2.47)\end{array}$ & $\begin{array}{c}-0.0009 \\
(0.86)\end{array}$ & $\begin{array}{c}-0.00038 \\
(1.39)\end{array}$ & $\begin{array}{l}0.00005 \\
(0.17)\end{array}$ \\
\hline $\ln K$ & $\begin{array}{l}-0.005 \\
(0.16)\end{array}$ & $\begin{array}{c}0.05 \\
(0.66)\end{array}$ & $\begin{array}{c}0.33 \\
(1.49)\end{array}$ & $\begin{array}{c}-0.23 \\
(0.68)\end{array}$ & $\begin{array}{c}1.73 \\
(3.85)\end{array}$ & $\begin{array}{c}-0.33 \\
(1.74)\end{array}$ \\
\hline $\ln L$ & $\begin{array}{c}1.10 \\
(22.51)\end{array}$ & $\begin{array}{c}1.02 \\
(9.26)\end{array}$ & $\begin{array}{c}1.70 \\
(5.01)\end{array}$ & $\begin{array}{c}2.05 \\
(4.56)\end{array}$ & $\begin{array}{c}1.41 \\
(2.91)\end{array}$ & $\begin{array}{c}2.53 \\
(5.70)\end{array}$ \\
\hline$[\ln K]^{2}$ & - & - & - & $\begin{array}{c}-0.018 \\
(0.36)\end{array}$ & $\begin{array}{c}-0.13 \\
(3.50)\end{array}$ & $\begin{array}{l}0.0004 \\
(0.01)\end{array}$ \\
\hline$[\ln L]^{2}$ & - & - & - & $\begin{array}{c}-0.40 \\
(4.35)\end{array}$ & $\begin{array}{c}0.04 \\
(0.30)\end{array}$ & $\begin{array}{c}-0.28 \\
(2.22)\end{array}$ \\
\hline $\ln L \ln K$ & - & - & - & $\begin{array}{c}0.21 \\
(1.76)\end{array}$ & $\begin{array}{c}-0.06 \\
(0.56)\end{array}$ & $\begin{array}{c}0.11 \\
(0.85)\end{array}$ \\
\hline $\ln K / \ln L$ & - & - & $\begin{array}{c}-0.11 \\
(1.81)\end{array}$ & - & - & - \\
\hline $\begin{array}{l}\text { Subsector } \\
\text { dummies }\end{array}$ & Yes & No & No & No & No & No \\
\hline $\bar{R}^{2}$ & 0.8944 & 0.8694 & 0.9110 & 0.7279 & 0.9638 & 0.9097 \\
\hline
\end{tabular}

Note. The instruments used were regional dummies, time dummies, the average age of workers and managers, the mode of creation of the firm, interest costs on internal and external loans, the proportion of equity held privately, and the debt/equity ratio. 
nificant coefficients, while LEND and RES each record one positive and one negative significant coefficient. The IV estimates are hence less conclusive and they highlight the positive productivity effect of workers' participation in management and, to a slightly lesser extent, of individual worker ownership of firms' assets. In view of the fact that adequate instruments could not be found for the French PCs, these results ought to be treated as tentative. With longer panel data being available for the French PCs in the relatively near future, it will be possible to provide more conclusive insights into the productivity effects within this PC sector.

\section{CONCLUSIONS}

Our results indicate that the productivity effects of various forms of worker participation differ markedly from one institutional setting to another. However, in general they support the prediction that the overall effect of the various participatory schemes observed in Western producer cooperatives is positive. In the OLS regressions, the positive effect is found most uniformly with respect to profit sharing and, to a slightly lesser extent, to individual capital (share) ownership by workers and participation in decision-making as measured by the proportion of workers who are members. Individual worker loans to the coop are not related to performance while collective capital ownership exhibits an insignificant or a negative productivity effect. In Italy and in the United Kingdom, where suitable instruments are available, the IV estimates strongly resemble their OLS counterparts. In France, where the predictive power of the available instruments is low, the IV results differ from the OLS ones and the IV results highlight the positive productivity effects of worker participation in decision-making and of individual capital ownership by workers.

Our general findings thus support the proponents of participatory schemes rather than their critics. The results suggest that, if higher productivity is the goal, PCs should provide for substantial sharing of profits and capital ownership by individual workers together with worker participation in decisionmaking. ${ }^{18}$ Collective ownership of assets ought to be avoided unless considerations other than productivity strongly justify its existence.

These broad policy conclusions must be tempered by the acute need for additional empirical research in this area. The comparative nature of our study highlights the diversity of findings across countries and economic sectors. The fact that the estimated effects are very significant in Italy and France and relatively insignificant in the United Kingdom points to the desirability of performing future analyses of the relevant institutional factors that differ con-

\footnotetext{
${ }^{18}$ See, however, Svejnar's (1982b) findings of virtually no significant productivity effects of codetermination in West Germany.
} 
siderably across the individual settings. We hope that our attempt to identify some of these factors in Section 2 of this paper are helpful in this future effort.

\section{APPENDIX: THE DATA AND THE VARIABLES}

\section{The Data}

The French data were gathered by a single agency (SCOP) to which most French PCs belong. The agency uses systematic procedures in gathering data. The data cover about 600 firms existing in 1978 and 1979 . More than $90 \%$ of the observations are for firms in relatively homogeneous industrial groupings: construction, consultancy, electrical engineering, and services.

The Italian data were gathered in a survey by the Lega Nazionale delle Cooperative (Lega), the organization to which most federated Italian PCs belong. The agency used systematic procedures in gathering data. Annual data were collected during 1975-1980 for individual PCs which had sales in excess of $\$ 1$ million in at least 1 year during this period. While some PCs barely exceed this cutoff, others are much larger. For example, the largest PC, CMC Ravenna, had sales exceeding $\$ 120$ million in 1978 and ranked as the 178th largest firm in Italy. More than 600 observations are available for large Italian PCs in manufacturing and construction.

Data on British PCs are for 1948-1968 and are available at 5-year intervals. Measures of valued added, capital, labor, and incentives are derived from data on individual PCs held by the Research Department of the Cooperative Union, Manchester. These data are abstracted from annual returns that societies make to the Cooperative Union. Measures of participation are derived directly, either from annual returns made by individual PCs to the Cooperative Union or from a similar report that, because of registration under the Industrial and Provident Societies Acts, societies are required to make on an annual basis to the Registrar of Friendly Societies.

Data on Spanish PCs are taken from Thomas and Logan (1982) and Campbell et al. (1977) which, in turn, are typically derived from data supplied by the Caja Laboral Popular. Data on U.S. PCs are taken from Gunn (1984).

\section{The Variables}

$$
\begin{aligned}
& V=\text { value added }=\text { total labor costs }+ \text { total capital costs }+ \text { surplus } \\
& (=\text { costo lavoro totale }+ \text { oneri fin. e int. passivi }+ \text { risultato } \\
& \text { d'esercizio = valeur adjoutée). } \\
& K=\text { capital = fixed assets at historical value (= immobiliz techniche } \\
& \text { or immobilisations nettes). } \\
& L=\text { labor = number of workers }=L_{x}+L_{n x}(=\text { lavorati fissi }=\text { effectif } \\
& \text { moyen des salariés). }
\end{aligned}
$$


$L_{x}=$ worker-members $(=$ soci fissi $=$ effectif societaires salariés).

$L_{n x}=$ non-member-workers (= ausiliari. fissi).

MEMB $=$ proportion of the workforce that is members $=L_{x} / L$.

SURPLUS $=$ surplus distributed to workers as a participation bonus.

BONUS $=$ average surplus distributed per worker $=\operatorname{surplus} / L($ where $\geq 0)$

(= risultato d'esercizio/ $L=$ dotation à la participation $/ L$ ).

OWN $=$ average capital stake per worker-member $=$ member capital/ $L_{x}$ (= capital sociale $/ L=$ capital social associés salariés $/ L_{x}$ ). LEND $=$ average loan capital per worker-member $=$ member loan capital $/ L_{x}$ (= prestito soci $/ L_{x}=$ comptes courants associés $/ L_{x}$ ).

RES $=$ average collectively owned reserves per worker-member $=$ collective reserves $/ L_{x}\left(=\right.$ fondi riserva $/ L_{x}=$ total fonds propres collectifs $\left./ L_{x}\right)$.

CONTROL $=$ proportion of total member capital owned by worker-members.

SHARE $=$ proportion of total assets owned by worker-members.

LOANS $=$ proportion of loans applied by worker-members.

LONG $=$ longevity $=$ number of years that $\mathrm{a}$ firm has been in existence.

Since all workers share in the firm's profits, BONUS is defined as profits distributed to the labor force per worker, rather than per member. While BONUS is available for French and British PCs, for Italian PCs we must use profits per worker, which is not an ideal measure of the amount actually distributed as income and the labor force. However, profits per worker tend to be roughly proportional to the actual worker bonuses. MEMB, the ratio of members to workers, is available everywhere except for the Italian construction industries where, since data do not exist on working vs nonworking (mostly retired) members, the numerator of MEMB is defined as the total number of coop members. An analysis of the Italian manufacturing data suggests that the discrepancy between working members and all members is not substantial.

\section{REFERENCES}

Alchian, A. A., and Demsetz, H., "Production, Information Costs, and Economic Organization." Amer. Econom. Rev. 62, 5:777-795, Dec. 1972.

Antoni, A., "Worker Cooperative in France." Ann. Collect. Economy 3, July-Dec. 1957.

Blasi, J., Ed., Producer Cooperative in Fifteen Countries. Norwood, 1983.

Cable, J., and Fitzroy, F., "Cooperation and Productivity: Some Evidence from West German Experience." Econom. Analysis Workers' Manage. 14, 163-180, 1980a.

Cable, J., and Fitzroy, F., "Production Efficiency, Incentives and Employee Participation: Some Preliminary Results for West Germany." Kyklos 33, 100-121, $1980 \mathrm{~b}$.

Campbell, A., et al., Worker Owners: The Mondragon Achievement. London: Anglo-German Foundation, 1977. 
Clayre, A., The Political Economy of Cooperation. Oxford: Oxford Univ. Press, 1980.

Cornforth, C., "Some Factors Affecting the Success or Failure of Worker Cooperatives: A Review of Empirical Research in the United Kingdom." Econom. Ind. Democr. 4, 163-190, 1983.

Cummings, E., "Co-operative Production in France and England." Q. J. Econom. 4, 357-386, July 1890.

Davidson, R., and MacKinnon, J. G., "Several Tests for Models Specification in the Presence of Alternative Hypotheses." Econometrica 40, 781-793, 1981.

Defourney, J., Estrin, S., and Jones, D. C., "The Effects of Worker Participation on Enterprise Performance: Empirical Evidence from French Cooperatives." Int. J. Ind. Org. 3, 197$217,1985$.

Estrin, S., "The Role of Producer Cooperatives in Employment Creation." Econom. Analysis Workers' Manage., in press.

Estrin, S., and Jones, D. C., "The Effects of Worker Participation upon Productivity in French Producer Cooperatives." Eur. Univ. Inst. Working Paper no. 68, 1983.

Freeman, R. B., "Individual Mobility and Union Voice in the Labor Market." Amer. Econom. Rev. 66, 2:361-368, May 1976.

Greenberg, E. S., "Producer Cooperatives and Democratic Theory: The Case of the Plywood Firms." In Jackall and Levin, Eds., Worker Cooperatives in America. Berkeley, CA: Univ. of California Press, 1984.

Gunn, C. E., Workers Self Management in the United States. Ithaca, NY: Cornell Univ. Press, 1984.

Hirshman, A. O., Exit, Voice and Loyalty. Cambridge, MA: Harvard Univ. Press, 1970.

Horvat, B., The Political Economy of Socialism. Armonk, NY: Sharpe, 1982.

Jensen, M. C., and Meckling, W. H., "Rights and Production Functions: An Application to Labor-Managed Firms and Codetermination." J. Bus. 52, 4:409-506, 1979.

Johnson, A., and Whyte, W. F., "The Mondragon System of Worker Cooperatives." Ind. Labor Relations Rev. 31, 1:18-30, 1977.

Jones, D. C., "U.S. Producer Cooperatives: The Record to Date." Ind. Relations 8, 2:342-356, Fall 1979.

Jones, D. C., "Producer Cooperatives in Industrialized Western Economies." Brit. J. Ind. Relations 18, 141-154, July 1980.

Jones, D. C., "American Producer Cooperatives and Employee Owned Firms: A Historical Perspective." In R. Jackall and H. Levin, Eds., Worker Cooperatives in America. Berkeley, CA: Univ. of California Press, 1984.

Jones, D. C., "British Producer Cooperatives 1948-1968: Productivity and Organizational Structure." In Jones and Svejnar, Eds., Participatory and Self-Managed Firms: Evaluating Economic Performance. Lexington, MA: Heath, 1982.

Jones, D. C., and Backus, D. L., "British Producer Cooperatives in the Footwear Industry: An Empirical Test of the Theory of Financing." Econom. J. 87, 488-510, Sept. 1977.

Jones, D. C., and Svejnar, J., Eds., Participatory and Self-Managed Firms: Evaluating Economic Performance. Lexington, MA: Lexington Books, 1982.

Jones, D. C., and Svejnar, J., "Participation, Profit Sharing, Worker Ownership and Efficiency in Italian Producer Cooperatives." Economica 52, 449-465, Nov. 1985.

Jones, D. C., and Zevi, A., "The Italian System of Producer Cooperatives." In J. Blasi, Ed., Producer Cooperatives in Fifteen Countries. Norwood, 1983.

Kmenta, J., "On the Estimation of the CES Production Function," International Economic Review, $8,1967$.

Meade, J. E., Wage Fixing: Stagflation, Vol. 1. London: Allen \& Unwin, 1982.

Nelson, R., "Research on Productivity Growth and Differences," J. Econom. Lit. 19, 3:10291064, Sept. 1981.

Oakeshott, R., The Case for Worker Cooperatives. London: Routledge \& Kegan Paul, 1978. 
Pesaran, M. H., and Deaton, A. S., "Testing Non-nested Non-linear Regression Models." Econometrica 46, 3:677-694, May 1978.

Pigou, A. C., Ed., Memorials of Alfred Marshall. London: Macmillan \& Co., 1925.

Samuelson, P. A., "Thoughts on Profit Sharing." Zeitschr. Gesamte Staadtswissenschaft, special issue, 1977.

Sertel, M., Workers and Incentives. Amsterdam: North Holland, 1982.

Steinherr, A., "On the Efficiency of Profit Sharing and Labor Participation in Management." Bell J. Econom., 545-555, Autumn 1977.

Svejnar, J., "On the Theory of a Participatory Firm." J. Econom. Theory 21, 2:313-330, Aug. $1982 a$.

Svejnar, J., "Codetermination and Productivity: Empirical Evidence from the Federal Republic of Germany." In D. Jones, and J. Svejnar, Eds., Participatory and Self-Managed Firms, pp. 199-212. Lexington, MA: Lexington Books, 1982b.

Thornley, J., Worker Cooperatives: Jobs and Dreams. London: Heinemann, 1981.

Thomas, H., and Logan, C., Mondragon: An Economic Analysis. London: Allen \& Unwin, 1982.

Vanek, J., The General Theory of Labor-Managed Market Economies. Ithaca, NY: Cornell Univ. Press, 1970.

Vanek, J., Ed., Self-Management: Economic Liberation of Man. London: Penguin, 1975.

Webb, S., and Webb, B., A Constitution for the Socialist Commonwealth of Great Britain. London: Longman, 1920. 